\title{
Agricultural Research and Extension Linkage: Review on Roles in an Improved Agricultural Technology Transfer in Ethiopia
}

\author{
Wasihun Alemnew \\ Ethiopian institute of agricultural research, Wondogenet agricultural research center, Ethiopia
}

\begin{abstract}
Agricultural research and extension services are two structures which can be connected via information flow, capacity building and feedback on the technology. Ethiopian agricultural research system is prepared by means of a decentralized structures in which there are federal and regional research institutes. The concept of linkage implies the communication and working relationship established between two or more organizations controlling commonly shared objectives in order to have regular contact and improved productivity. The ultimate objective of both research and extension systems is to increase agricultural production. Their roles of generating and transferring technology are complementary.Agricultural research and extension are complementary acticities to achieve the common goal of increasing agricultural productivity. Strong formal linkage, coordination and cooperation among research centers, development agents and farmers need to be created on the technologies of research centers are able to implement on farmers field and improve the livelihood of smallholder farmers.
\end{abstract}

Keywords: role, linkage, research and extension, technology transfer

DOI: $10.7176 / \mathrm{JNSR} / 13-4-02$

Publication date: February $28^{\text {th }} 2022$

\section{Introduction}

Agricultural research and extension services are two structures which can be connected via information flow, capacity building and feedback on the technology. Ethiopian agricultural research system is prepared by means of a decentralized structures in which there are federal and regional research institutes. There has been no coordinating organisation in Ethiopia but currently, the Ethiopia Agricultural research Council is being established. The connection among the federal and regional research institutes changed into competitive than collaborative( Tilaye and Daneil, 2016).

The extension employer also has a decentralized structure that consists of the federal ministry of agriculture, the regional bureau of agriculture, zonal agricultural workplace and the district places of work of agriculture. There's large number of extension personnel that there are three or more development agents in every kebele. There's also one farmer training center in most of the kebeles. Agricultural extension will be one tool in reaching the sustainable improvement goal associated with the reduction of excessive poverty and hunger in developing nations like Ethiopia. Although extension become declined for decades in Ethiopia, it's far recently that smallscale farmers have got interest (Alemayehu and Musaba, 2020).

The absence of powerful linkage organization among agricultural research and extension structures has one of the principal reasons for the low productiveness of Ethiopian agriculture. Recent empirical research in developing nations have identified weak links among research and extension because lack of appropriate flow of facts, understanding and useful new technologies among actors (Anderson and Feder, 2004). In the absence of clear guidelines, research and extension employees conduct their task on the ones mandate. Most of the time research and extension was give a low priority to linkage, mainly while research and extension activities are administered by external dooners. however, linkage activites can't be achieved in isolation; they require coordination of personnel from both research and extension organization (Belay, 2003).

Technology generation as a main component of technology development and research coordination was started in the country in the 1960's. Since then, technology transfer and linkage remained as peripheral responsibilities. Through the course of time, however, a number of efforts were made to improve technology transfer and linkage practices. Several attempts were made in the past to bring strong linkage, coordination, collaboration and efficient delivery of research and extension services to the farming community (EARO, 1998). 
Table-1: historical evolution of linkage organizations in Ethiopia

\begin{tabular}{|l|l|l|}
\hline Linkages & Year & Role \\
\hline $\begin{array}{l}\text { Institute of Agricultural } \\
\text { Research(IAR) }\end{array}$ & 1974 & $\begin{array}{l}\text { Technology package testing and formulation of research } \\
\text { recommendations }\end{array}$ \\
\hline Farming system research(FSR) & 1980 s & Providing feedback to researchers \\
\hline $\begin{array}{l}\text { Research-Extension Liaison } \\
\text { Committee (RELC) }\end{array}$ & 1986 & $\begin{array}{l}\text { Disseminating agricultural technologies } \\
\text { coordinating demonstrations, training, and linkage activities }\end{array}$ \\
\hline $\begin{array}{l}\text { Research-Extension-Farmers } \\
\text { Linkage Advisory Council (REFAC) }\end{array}$ & 1990 & $\begin{array}{l}\text { manage women and farmer representatives in research } \\
\text { process } \\
\text { control FRG and working groups }\end{array}$ \\
\hline $\begin{array}{l}\text { Agricultural development partners } \\
\text { linkage advisory council (ADPLAC) }\end{array}$ & 2008 & Coordinating agricultural development stakeholders \\
\hline
\end{tabular}

Source: (FDRE 1999; MOA 2012 and Tilaye and Danil, 2016)

An agricultural research system is a complex set of linkages among different partners. To improve agricultural productivity and farmer income, while saving limited resources and addressing equity concerns require an interactive approach whereby research, extensions and farmers work together in co-ordinated manner, currently there is a weak linkage between organisations in the agricultural technology transfer system (Oladele,2013). The aim of this review is to assess the importance of research-extension linkages for improved technology transfer in Ethiopia. The method of study is thorough review of existing literature on research and extension linkages.

\section{Literature review}

\subsection{Definition and concepts}

The concept of linkage implies the communication and working relationship established between two or more organizations controlling commonly shared objectives in order to have regular contact and improved productivity (Havelock, 1986). Research-extension linkage involves the use of extension workers (Agricultural development agents, subject mater specialist..), farmers and researchers. Extension can provide information and facilitate interaction between researchers and farmers. Simultaneously, extension also requires a constant flow of information on new and improved practices, necessitating a two-way communication process. Reasons for the need for strong linkages include influencing formulation of research agendas based on problem identification, and the need to evolve technology suitable for the prevailing socio-economic and ecological environment. The concept of technology flow is fundamental to the design of research and extension systems. This facilitates diagnosis of research-extension linkage problems (Chambers, 1983).

\subsection{Role of research and extension linkage for technology transfer}

The ultimate objective of both research and extension systems is to increase agricultural production. Their roles of generating and transferring technology are complementary. Research institutions need to have information on the problems and technology requirements of producers to formulate research proposals and to set priorities. Formulating a research agenda based on farmers needs results in technology that will be more acceptable to users; this also leads to research institutions allocating their resources more efficiently (Galfato, 2019).

Extension services can provide research institutions with information on research requirements and play a mediatory role between farmers and researchers. Extension services require a continuous flow of information from research institutions on new and improved practices. Therefore an efficient two-way communication process is necessary for generating and transferring technology effectively. The success of the two-way communication is determined mainly by the effectiveness of linkage between research and extension institutions. For researchers or extension workers to become successful in their role implementing collaborative approaches, they may need to engage interactions among actors (tropical agriculture platform, 2016). They may further be required to participate in linking and strategic networking, providing technical backstopping and capacity building. As such, researchers or extension professionals increasingly require complex capacities at the individual level, such as having first-hand knowledge of the topic, showing leadership, facilitating multistakeholder processes, building trust, resolving conflict and having good communication skills (Mur and Nederlof, 2011).

Development agents facilitate to promote modern agricultural practices with close technical guidance of farmer's to use environmentally adapted agricultural technologies throughout the nation. Accordingly, the dependence of development agents on research centers for the supply of improved technologies to the farmers remains infeasible in the southern region in particular and in the country in general. So, strong coordination and interaction between researchers and development agents to implement on farmers field and improve the livelihood of smallholder farmers. As a result, the absence of formal linkage between extension workers and researchers denies DAs to access and disseminate environmentally friend and socially sound new 
technologies produced in research centers to farmers at the time of need (Gebrehiwot et'al, 2012).

Table-2: The roles and responsibilities of key partners in the process of technology transfer

\begin{tabular}{|l|l|l|l|}
\hline No. & Actors & Organization & Major roles \\
\hline 1. & $\begin{array}{l}\text { Research } \\
\text { centers }\end{array}$ & $\begin{array}{l}\text { Public research } \\
\text { institute }\end{array}$ & $\begin{array}{l}\text { Conducting adaptation trails Demonstrationing best practices } \\
\text { Provding trainings to development agents and farmers Providing } \\
\text { intial technology (seed) to farmers }\end{array}$ \\
\hline 2. & $\begin{array}{l}\text { Agricultural } \\
\text { office }\end{array}$ & $\begin{array}{l}\text { Government } \\
\text { office }\end{array}$ & $\begin{array}{l}\text { Coordinating and supervising development agents Access to } \\
\text { extension service to farmers Linkage between farmers and } \\
\text { researchers } \\
\text { Selecting farmers and land for technology verification and } \\
\text { demonstration }\end{array}$ \\
\hline 3. & Farmers & Producers & $\begin{array}{l}\text { Provide land and labor } \\
\text { Cultivation of the activity } \\
\text { End user of the product }\end{array}$ \\
\hline 4. & & & \\
\hline
\end{tabular}

Source : EIAR experience

\subsection{Technology flow processes}

Technology flow involves sequential processes along the research-extension-farmers continuum. They are technology generation by researchers, technology testing and integration by extension workers, dissemination, diffusion and adoption. The transfer of technology model (Chambers, 1983) is most common, where findings developed by researchers are transferred to extension for delivery to users. This is a one-way, linear process and similar to the progressive farmer approach. This assumption of a linear, sequential flow of technology has been criticized by many social scientists as it ignores the actual contribution and potential of farmers as generators of technology (Javier, 1989). The model also neglects policy-driven, market-driven, and farmer-driven innovation. Several other models - such as the technology innovation process the research-extension process, the technology generation and delivery process; and the agricultural technology development system have been developed to describe technology flow. These models have been synthesized in the research-extension interface model (Javier, 1989).

Currently implementing linkage approaches in Ethiopia, to strengthen research-extension collaborations are as follows institutional linkages of National Agricultural Research System (NARS) with actors of formal agricultural technology transfer systems, technology demonstration and popularization, Farmers' Research Groups (FRGs), Technology specific special pre-extension activities, Publications and Agricultural Development Partners' Linkage Advisory Councils (ADPLACs) as research-extension linkage platforms (Belay and Dawit, 2017).

Evolving new agricultural technology generation and its fast dissemination requires a sequence of communicating concerned stakeholders. As stated above, the process of agricultural technology generation requires a number of interrelated partners and steps carried out by some of institutes such as research institutions, extension organizations and farmers'. Currently, research institutes are shifted from technology generation on station to farmers field and create collaboration between researchers, extension workers and farmers. But, now not all of those technologies have reached farmers' fields and there's gaps between potential and actual agricultural production. Efforts are being made to change extension contributions in lots of growing international locations, but studies institutes, in addition to their most important research outputs, have also a key role to play in the transfer of stepped forward farm and the upgrading of the expert competence of extension employees and farmers.

informal linkage mechanisms based on friendship and mutual interest include the promotion of joint social activities and using present personal ties. Japan's research-extension linkage device offers a range of possibilities for farmers' participation in joint decision-making on research themes. The stron research-extension linkage in Japan can in part be attributed to the change of personnel among agricultural research and extension collaboration (Agbamu, 2000).

\section{Conclusion and recommendation}

\subsection{Conclusion}

Agricultural research and extension are complementary acticities to achieve the common goal of increasing agricultural productivity. Due to different reasons, the linkage among research and extension has been weak. This has affect timely dissemination and adoption of imprived agricultural technologies. existing agricultural research and extension systems are organized in most cases under separate administrative devices. The linkage among research and extension institutions is weak, in particular in shifting remarks from farmers to researchers. Furthermore, there was no formal liaison between research and extension that could foster dissemination of 
ecologically friend, socially sound and market oriented agricultural technologies produced in research centre through DAs to the intended group of farmers on the time of need.

\subsection{Recommendation}

Strong formal linkage, coordination and cooperation among research centers, development agents and farmers need to be created on the technologies of research centers are able to implement on farmers field and improve the livelihood of smallholder farmers.

- Mainstreaming of the culture of partnership in the technology promotion through awareness creation and capacity building

- $\quad$ Strengthening ADPLAC by allocating its own necessary logistics to sustain itself

- $\quad$ indicating specific roles and responsibility of partners involving in the process of linkages activities

- Establishing regular issue-based and periodic discussions among stakeholder shared roles and responsibilities

\section{Reference}

Agbamu, (2000). Agricultural research-extension linkage systems: an international perspective. Agricultural research and extension network, Network Paper No.10.6

Alemayehu and Murbsa, (2020). Review on Agricultural Extension Impacts on Food Crop Diversity and the Livelihood of Farmers in Ethiopia

Anderson, J, R. and Feder, G. (2004) Agricultural Extension: Good Intentions and Hard Realities, The World Bank Research Observer. 19(1): 41 - 60

Javier,(1989). Recent approaches in the study and management of the linkages between agricultural research and extension. ISNAR Staff Notes, No. 89-63

Galfato, (2019). Innovation platforms- as effective extension approach to introduce Rhizobia technology in southern Ethiopia. Agri. Res and tech. open acess J.19(3).

Gebrehiwot, Kinfe and Deribe,2012. Challenges of development agents performance in technology diseemination: case from southern nations nationalities and peoples regional state, Ethiopia. J. agri. Science,2(9):208-016.

MoA , (2012b).Performance of agricultural developmentpartners linkage advisory councils. RCBP Project, Ministry of Agriculture, Addis Ababa.

Havelock (1986). A Key to understanding the knowledge system in Beal, G.M., Dissanayake, W. and Konoshima, S.(Eds.). Knowledge Generation, Exchange and Utilization. Boulder, Colorado. West view Press.

FDRE, (1999) Agricultural research and training project: Ethiopian research-Extension-farmer linkages strategy, vol I. FDRE, Addis Ababa

Belay and Dawit ,(2017). Agricultural research and extension linkages: challenges and intervention options. Ethiopian journal of agricultural science. 27(1): 55-76.

Belay, (2003). Agricultural Extension in Ethiopia: the case of participatory demonstration and' training extension system. J. Social Dev. Afr. 8(1)49-84.

Oladele, (2013). Linkage between gown and town: My experience in sub-Saharan Africa and South East Asia: Inaugural lecture: North West University (Mafikeng Campus),

Tilaye and Daniel, (2016). Agricultural Research and Extension Linkages in the Amhara Region, Ethiopia. In Technological and Institutional Innovations for Marginalized Smallholders in Agricultural Development, edited by Franz W. Gatzweiler and Joachim von Braun, 113-124. Cham, Switzerland: Springer. 